Berenice Scaletzky Knuth ${ }^{1}$

Ricardo Azevedo da Silva ${ }^{2}$

Jean Pierre Oses ${ }^{1}$

Vinicius Augusto Radtke ${ }^{1}$

Rafaela Abreu Cocco ${ }^{1}$

Karen Jansen ${ }^{1}$

\title{
Mental disorders among health workers in Brazil
}

\author{
Transtornos mentais entre trabalhadores da área da saúde no Brasil
}

${ }^{1}$ Programa de PósGraduação em Saúde e Comportamento, Centro de Ciências Biológicas e da Saúde, Universidade Católica de Pelotas (UCPel). R. Felix da Cunha 412, Centro. 96010-000 Pelotas RS Brasil.

bscaletz@terra.com.br ${ }^{2}$ Curso de Psicologia, Escola de Psicologia, UCPel.
Abstract The scope of this article is to determine the prevalence of common mental disorders (CMD) and Depression among Community Health Agents (CHA) and employees of Psychosocial Care Centers (CAPS). It is a cross-sectional descriptive study involving the target population of Community Health Workers and Psychosocial Care Center workers, linked to the Municipal Health Department of Pelotas in the Brazilian State of Rio Grande do Sul. The presence of common mental disorders was considered when the Self Report Questionnaire (SRQ) was > 7 and the occurrence of depression when BDI $>12$. In total, 257 professionals participated in the study. Among mental health professionals $(n=119)$, the prevalence of CMDs was $25.2 \%$ and depression was $23.5 \%$, while the prevalence of CMDs was $48.6 \%$ and depression was 29\% among CHA $(n=138)$. The ratio of CMDs between the two groups of professionals was statistically different $(p<0.001)$. In this study, it was observed that the CAPS professionals are more adapted to work issues, with less perceived health problems arising from work and with a lower prevalence of mental disorders compared to CHA.

Key words Health care professionals, Mental disorders, Depression, Community health agent, Psychosocial care center
Resumo Este artigo tem por objetivo verificar a prevalencia de transtornos mentais comuns (TMC) e Depressão entre Agentes Comunitários de Saúde (ACS) e trabalhadores dos Centros de Atenção Psicossocial (CAPS). Estudo descritivo transversal, tendo como população alvo os Agentes Comunitários de Saúde e os trabalhadores dos Centros de Atenção Psicossocial, vinculados à Secretaria Municipal de Saúde de Pelotas, RS, Brasil. A presença de transtornos mentais comuns foi considerada quando o Self Report Questionnaire $(S R Q)>7$ e a ocorrência de depressão quando Beck Depression Inventory II (BDI II) > 12. No total, 257 profissionais participaram do estudo. Dentre os profissionais da saúde mental $(n=119)$, a prevalência de TMC foi de 25,2\% e de depressão de 23,5\%. Já a prevalência de TMC foi de 48,6\% e de depressão de 29,0\% entre os ACS $(n=138)$. A proporção de TMC entre os dois grupos de profissionais foi estatisticamente diferente $(p<0.001)$. Neste estudo, pode-se observar que os profissionais dos CAPS estão mais adaptados às questões laborais, percebem-se com menor prejuizo para a saúde decorrente do trabalho e também apresentaram menor prevalência de transtornos mentais quando comparados aos ACS.

Palavras-chave Profissionais da saúde, Transtornos mentais comuns, Depressão, Agente comunitário de saúde, Centro de Atenção Psicossocial 


\section{Background}

The world of work has undergone numerous transformations in many ways such as: economic, political, social and technical. These changes have a strong influence on the health of workers ${ }^{1}$. The daily experiences of suffering and difficulties have led to mental illness these professionals ${ }^{2}$.

According to data from the World Health Organization (WHO), depressive disorders are in fourth place among the ten leading causes of disability worldwide 3 . Another important finding is the fact that depressive disorders have represented the third health problem among women in developed countries and the fifth in underdeveloped countries. These disorders also contribute a third of days lost to sickness at work, and in a fifth of all primary care consultations ${ }^{4}$. In Rio Grande do Sul, Brazilian federal state, according to the Center for Public Health Surveillance, mental disorders are the second leading cause of absenteeism from work ${ }^{5}$.

In light of the research results, the illness of health professionals has attracted the attention of researchers. Several studies have shown that mental illnesses have brought great harm to the professionals in this area 5 .

Factors that are part of everyday life here in the professional study such as dealing with human suffering, great job demands and low recognition; are among the aspects that cause diseases $^{6,7}$. Moreover, the working process used by these professionals generates difficulties and labor overhead, making them even more vulnerable to suffering to which they are exposed daily ${ }^{8}$.

In the last decade there have been some changes in the way we treat health in Brazil. Can highlight among them the creation by the Ministry of Health of Brazil, a new category of health professionals, namely the Community Health Agents. Moreover, there was also a change in the way of work of some professionals in this area, as the workers of Psychosocial Care Centers.

In 1991, the Ministry of Health (MOH) created the Program of Community Health Agents. Since 1994 these agents work in the Family Health Program (PSF) ${ }^{9}$. The Community Health Agents (ACS) act as a link between the family health team (FHT) and the community and bridge the gap between scientific knowledge and popular knowledge ${ }^{10}$.

In the area of Mental Health, in 1987 was created the first Center for Psychosocial Care (CAPS), followed by the creation of other centers. The goal was to implement a new model of mental health. The CAPS is characterized as community service regionalized outpatient, facing the treatment and psychosocial rehabilitation. Thus, the mental health workers also had their form of work modified ${ }^{11}$.

From the perspective of this study, these new ways of doing the work of health can lead to both physical and mental illness. Whereas on the one hand, potential harmful to the health care worker is exposed, and on the other hand, the lack of information about the actual health situation of these professionals, this study aims to assess the prevalence of Common Mental Disorders, Depression and o Perception of Psychological Well-Being between community agents health and mental health professionals linked to the Municipal Health Secretaria of Pelotas, Brazil.

\section{Methods}

\section{Design}

This is a cross-sectional comparative study among health professionals of the municipality of Pelotas. The target population consisted of two groups: 1) Community Health Agents (CHA) and 2) staff of the Centers for Psychosocial Care (CAPS).

\section{CHA Sample}

The group of CHA was captured during a training program on safety and health at work done by the Reference Center of Occupational Health (CEREST MACROSUL) that occurred in November 2012. In total, 181 professionals were invited to attend the event and respond to survey instruments. Professionals who voluntarily agreed to participate and signed the informed consent were included in the study.

\section{CAPS Sample}

Eight CAPS professionals participated in the study. Being six Centers for Psychosocial Care (CAPS) for people with severe and persistent mental disorders, CAPS for people with alcohol and other drugs (AD), CAPS-i that serves children and adolescents with severe and persistent mental disorders. As the records of the Municipal Health Secretariat of Pelotas, CAPS have $164 \mathrm{em}-$ ployees, the following professions: Doctors, psychologists, social workers, nurses, nursing technicians, craftsmen, senior technicians in arts, music 
and physical education, damage reducers, administrative officials and employees of hygiene.

CAPS professionals have been captured through scheduled visits in their workplace, those who did not attend the team meeting were visited later. Was considered lost when lack of professionals in service, after three scheduled visits.

\section{Variables and Instruments}

The research instrument used was a questionnaire consisting of sociodemographic information such as age, education, economic status and marital status. Aspects related to work and health were also analyzed, including the perception of psychological well-being. The economic classification was performed using the criteria of the Brazilian Association of Research Companies $^{12}$, which is based on the accumulation of material goods and education of household head. This classification fits people into classes (A, B, $\mathrm{C}, \mathrm{D}$, or $\mathrm{E})$ from the scores achieved, in which the letter " $A$ " refers to the highest socioeconomic status and "E" the lowest.

For investigation of depression Beck Depression Inventory II (BDI II) was used, a self-administered instrument whose purpose is to measure the severity of depression by assessing factors such as hopelessness, irritability, feelings of guilt and punishment, as well as physical symptoms such as fatigue, weight loss and decreased libido. It consists of 21 items covering the last 15 days, which are rated on a scale of 0 to 3 , giving scores ranging from 0 to 63 . This study will consider the presence of depressive episode when $\mathrm{BDI} \geq 12$ points ${ }^{13}$.

For investigation of Common Mental Disorders was applied the Self Report Questionnaire (SRQ-20). Composed of 20 questions on psychosomatic symptoms for tracking non-psychotic disorders, including depression, anxiety symptoms and somatic complaints. The SRQ-20 is recommended by the World Health Organization studies for community and primary health care ${ }^{14}$. The cutoff point used is seven, which according to the validation of Gonçalves et al. ${ }^{15}$ presents the following psychometric standards: $86.33 \%$ sensitivity and $89.31 \%$ specificity.

\section{Data Analysis}

After checking consistency of double data entry using Epi-Info 6.04d, proceeded to statistical analyzes using SPSS 21 software. Initially, data were presented as absolute and relative frequen- cies in order to describe the total sample and the two groups. Differences between groups were tested using the chi-square and were considered statistically significant when $\mathrm{p}<0.05$.

\section{Ethical Aspects}

As the data collection was conducted through self-report instrument, the professionals were oriented about the cutoffs of instruments and received information about where to seek individual assistance if necessary. The project was approved by the Ethics Committee in Research of the Catholic University of Pelotas (UCPel).

\section{Results}

\section{Percentage of losses and refusals}

The CHA group consisted of 181 professionals, no one refused to participate in the study and the percentage of losses was $23.7 \%(n=43)$, thus producing a sample of 138 individuals. CAPS professionals comprised a total of 153 subjects, of whom we obtained $9.1 \%(\mathrm{n}=14)$ of refusals and $13.1 \%(n=20)$ of losses, then remaining 120 individuals.

\section{Characteristics of the sample}

In total, 258 health professionals participated in the study. Being $86 \%$ female, $60.7 \%$ aged 40 years and $57.5 \%$ were married or living with a partner. The predominant economic rating was B (66.9\%) and 52.9\% had completed high school or had incomplete higher.

Compared the sociodemographic characteristics between the groups, CAPS professionals have increased age $(\mathrm{p}<0.001)$, higher level of education $(\mathrm{p}<0.001)$, higher economic status $(\mathrm{p}<$ 0.001 ), higher proportion of separated/divorced/ widowed ( $\mathrm{p}$ 0.018) when compared with CHA (Table 1).

\section{Work Related Aspects}

In this sample, all work-related issues were different between groups of professionals. Thus, it was found that CAPS professionals reported more years of service in healthcare and the current function $(\mathrm{p}<0.001)$, lower workload in this study $(\mathrm{p}<0.001)$ and the total workload $(\mathrm{p}<$ $0.001)$. Moreover, a greater proportion have another job ( $\mathrm{p}<0.001)$, miss less work $(\mathrm{p}<0.001)$, 
Table 1. Socio-demographic and economic characteristics of the sample of professionals and compared between groups. Pelotas, 2012.

\begin{tabular}{|c|c|c|c|c|}
\hline $\begin{array}{l}\text { Sociodemographic } \\
\text { caracteristics }\end{array}$ & $\begin{array}{c}\text { Sample } \\
\text { Distribution }\end{array}$ & $\begin{array}{c}\text { CAPS } \\
\text { Professionals }\end{array}$ & $\begin{array}{l}\text { Community } \\
\text { Health Agents }\end{array}$ & $\begin{array}{c}\text { P- } \\
\text { value }\end{array}$ \\
\hline \multicolumn{5}{|l|}{ Gender } \\
\hline Male & $36(14.0)$ & $21(17.5)$ & $15(10.9)$ & 0.176 \\
\hline Female & $222(86.0)$ & $99(82.5)$ & $123(89.1)$ & \\
\hline Age Group (years) & & & & $<0.001$ \\
\hline$<30$ & $74(28.8)$ & $14(11.8)$ & $60(43.5)$ & \\
\hline 31 a 40 & $82(31.9)$ & $35(29.4)$ & $47(34.1)$ & \\
\hline 41 a 50 & $56(21.8)$ & $36(30.3)$ & $20(14.5)$ & \\
\hline Over 50 & $45(17.5)$ & $34(28.6)$ & $11(8.0)$ & \\
\hline Education & & & & $<0.001$ \\
\hline Fund. or incomplete high & $22(8.6)$ & $8(6.7)$ & $14(10.1)$ & \\
\hline Average comp. incomplete or higher & $136(52.9)$ & $30(25.2)$ & $106(76.8)$ & \\
\hline Complete College & $28(10.9)$ & $15(12.6)$ & $13(9.4)$ & \\
\hline Postgraduate & $71(27.6)$ & $66(55.5)$ & $5(3.6)$ & \\
\hline Economical Classification & & & & $<0.001$ \\
\hline A & $19(7.4)$ & $19(16.0)$ & - & \\
\hline $\mathrm{B}$ & $172(66.9)$ & $82(68.9)$ & $90(65.2)$ & \\
\hline $\mathrm{C} / \mathrm{D}$ & $66(25.7)$ & $18(15.1)$ & $48(34.8)$ & \\
\hline Marital Status & & & & 0.018 \\
\hline Single & $63(24.8)$ & $24(20.5)$ & $39(28.5)$ & \\
\hline Married/living with partner & $146(57.5)$ & $64(54.7)$ & $82(59.9)$ & \\
\hline Separated/divorced/widowed & $45(17.7)$ & $29(24.8)$ & $16(11.7)$ & \\
\hline Total & 258 & 120 & 138 & --- \\
\hline
\end{tabular}

fewer are injured at work ( $p$ 0.029) and a lower percentage reported in the perception of injury to health arising from work ( $\mathrm{p} 0.005)$ when compared with CHA (Table 2).

\section{Aspects related to health}

As for relevant health aspects of the professionals involved in the research, it was observed that $60.9 \%$ had at least one medical visit in the past 90 days and $65.7 \%$ used any medication in the last 30 days. The perception of psychological well-being was reported by $70.8 \%$ of the sample, however, $37.7 \%$ were indicative of common mental disorders and $26.5 \%$ were in a current depressive episode.

When checked the difference between the groups, there was greater awareness of psychological well-being ( $p$ 0.016) and a lower prevalence of common mental disorders $(\mathrm{p}<0.001)$ between the CAPS professionals than among CHA, but no difference was found statistically between groups regarding the presence of current depressive episode (Table 3 ).

\section{Discussion}

Although the sample is composed of health professionals, the groups are quite distinct in terms of socioeconomic and demographic characteristics, as well as, with regard to work-related aspects. Moreover, it was observed that one third of the sample did not realize with psychological well-being and was also high prevalence of common mental disorders and depression among professionals. Being reported by the CHA a worse perception of psychological and higher prevalence of CMD than among CAPS professionals wellbeing. No statistical difference between the occurrence of depressive episodes in groups of CHA and CAPS professionals was observed, however, it should be noted that the measure includes CMD depressive symptoms, but also assesses anxiety symptoms and somatoform complaints; it is possible that the occurrence of these symptoms is more evident among CHA.

Since the CHA belong to a lower socioeconomic class and have a worse perception of psychological well-being and a higher prevalence of 
Table 2. Aspects related to work among professionals and comparison between groups. Pelotas, 2012.

\begin{tabular}{|c|c|c|c|c|}
\hline $\begin{array}{l}\text { Aspects related } \\
\text { to work }\end{array}$ & $\begin{array}{c}\text { Sample } \\
\text { Distribution }\end{array}$ & $\begin{array}{c}\text { CAPS } \\
\text { Professionals }\end{array}$ & $\begin{array}{l}\text { Community } \\
\text { Health Agents }\end{array}$ & $\begin{array}{c}P- \\
\text { value }\end{array}$ \\
\hline Time working in health & & & & $<0.001$ \\
\hline$\leq 42$ months & $126(49.8)$ & $26(22.4)$ & $100(73.0)$ & \\
\hline$>42$ months & $127(50.2)$ & $90(77.6)$ & $37(27.0)$ & \\
\hline Weather that is in the current function & & & & $<0.001$ \\
\hline$\leq 42$ months & $147(58.1)$ & $50(43.1)$ & $97(70.8)$ & \\
\hline$>42$ months & $106(41.9)$ & $66(56.9)$ & $40(29.2)$ & \\
\hline Hours in CAPS or with CHA & & & & $<0.001$ \\
\hline$\leq 30$ hours & $123(48.0)$ & $93(78.8)$ & $30(21.7)$ & \\
\hline$>30$ hours & $133(52.0)$ & $25(21.2)$ & $108(78.3)$ & \\
\hline Have another job & & & & $<0.001$ \\
\hline not & $169(66.0)$ & $60(50.8)$ & $109(79.0)$ & \\
\hline yes & $87(34.0)$ & $58(49.2)$ & $29(21.0)$ & \\
\hline Total workload & & & & $<0.001$ \\
\hline$\leq 30$ hours & $82(32.2)$ & $56(47.9)$ & $26(18.8)$ & \\
\hline$>30$ hours & $173(67.8)$ & $61(52.1)$ & $112(81.2)$ & \\
\hline Lack at work (last 30 days) & & & & $<0.001$ \\
\hline not & $199(77.7)$ & $90(76.3)$ & $109(79.0)$ & \\
\hline yes & $57(22.3)$ & $28(23.7)$ & $29(21.0)$ & \\
\hline Accident at work & & & & 0.029 \\
\hline not & $220(82.0)$ & $104(88.1)$ & $106(76.8)$ & \\
\hline yes & $46(18.0)$ & $14(11.9)$ & $32(23.2)$ & \\
\hline Perception of injury to health arising from work & & & & 0.005 \\
\hline not & $95(37.1)$ & $55(46.6)$ & $40(29.0)$ & \\
\hline yes & $161(62.9)$ & $63(53.4)$ & $98(71.0)$ & \\
\hline Total & 258 & 120 & 138 & --- \\
\hline
\end{tabular}

Table 3. Aspects related to health among professionals and comparison between groups. Pelotas, 2012.

\begin{tabular}{|c|c|c|c|c|}
\hline $\begin{array}{l}\text { Aspects related } \\
\text { to health }\end{array}$ & $\begin{array}{c}\text { Sample } \\
\text { Distribution }\end{array}$ & $\begin{array}{c}\text { CAPS } \\
\text { Professionals }\end{array}$ & $\begin{array}{l}\text { Community } \\
\text { Health Agents }\end{array}$ & $\begin{array}{c}\mathrm{P}- \\
\text { value }\end{array}$ \\
\hline Consulted a doctor in the past 90 days & & & & 0.718 \\
\hline not & $100(39.1)$ & $48(40.7)$ & $52(37.7)$ & \\
\hline yes & $156(60.9)$ & $70(59.3)$ & $86(62.3)$ & \\
\hline Medication use in past 30 days & & & & 0.186 \\
\hline not & $95(37.3)$ & $38(32.5)$ & $57(41.3)$ & \\
\hline yes & $160(65.7)$ & $79(67.5)$ & $81(58.7)$ & \\
\hline Perception of Psychological Well-Being & & & & 0.016 \\
\hline 4-7 (barely) & $74(29.2)$ & $25(21.4)$ & $49(36.0)$ & \\
\hline $1-3$ (Well) & $179(70.8)$ & $92(78.6)$ & $87(64.0)$ & \\
\hline Common Mental Disorders & & & & $<0.001$ \\
\hline not & $160(62.3)$ & $89(74.8)$ & $71(51.4)$ & \\
\hline yes & $97(37.7)$ & $30(25.2)$ & $67(48.6)$ & \\
\hline Depression & & & & 0.397 \\
\hline not & $189(73.5)$ & $91(76.5)$ & $98(71.0)$ & \\
\hline yes & $68(26.5)$ & $28(23.5)$ & $40(29.0)$ & \\
\hline Total & 258 & 120 & 138 & --- \\
\hline
\end{tabular}

CMDs, this study supports the idea that social vulnerability increases the likelihood of mental disorders. According to WHO (World Health Organization), the poor and the disadvantaged have 
a higher prevalence of mental and behavioral disorders ${ }^{16}$. Nevertheless, Dilélio et al. ${ }^{17}$ investigated the prevalence of minor psychiatric disorders in workers of primary health care in the South and Northeast regions of Brazil and observed higher prevalence of CMD between CHA and other mid-level professionals than among higher education professionals. Similar to our finding, since CAPS professionals have education and higher than the CHA, which indicates that psychological distress may be due to their lower pay and poorer working conditions economic classification, since the income provides access to best living conditions and lack of money can lead to stress and insecurity, causing psychological mechanisms of $\mathrm{CMD}^{18}$. Regardless of the economic and social aspects, studies on the impact of work on health of health workers have been growing in Brazil. This reflects the pressure of professionals and identifying significant number of cases relating to work-tioned among these individuals illness ${ }^{8}$. It is also reported mental illness resulting from overwork, cognitive and emotional overload generated by the nature of the task and the conditions under which it is executed ${ }^{19}$.

In the literature review, current studies have attack for mental health workers in the health field, however CAPS are studied mainly on a qualitative approach ${ }^{20,21}$.

Silva e Menezes ${ }^{22}$ found that the prevalence of common mental disorders was $43.3 \%$ in the CHA in São Paulo. Concluded that the high frequency levels of burnout among CHA raises the need for intervention strategies in the daily lives of these individuals and in the new investigations. Furthermore, Braga et al. ${ }^{23}$ found that the occurrence of CMD in the population of workers from primary health Botucatu was $42 \%$. This reports that professionals are subjected to high psychological demands at work. Settles-hence the paradox represented by work situations that contribute to the illness of workers, whose activities are the promotion and restoration of health of others. Rodrigues et al. ${ }^{24}$ found the prevalence of CMD in nursing workers at a general hospital in the state of Bahia was $35.0 \%$. The results indicated that the working and health conditions observed were not good and suggest that further researches on the characteristics and risks to workers' health should be made.

We notice that there are a number of factors that prevent professionals to perform satisfac- torily his work, as evidenced by the lack of materials and resources in general. In this context, the working conditions are not always ideal, and so the professional cannot meet the needs of patients in their health. The table ends up bringing frustration to professionals involved ${ }^{8}$. This situation can also lead to mental disorders ${ }^{25}$. Menegolla et al. ${ }^{26}$ describe that the major difficulties of CHA in their day to day are the lack of understanding of the population of his work, the high number of people in the community to be served, limitations as resolute of community problems, lack of organization, companionship and camaraderie of the multidisciplinary team, and the refusal of some professional team to conduct home visits.

In this study, we encountered a high percentage of losses and refusals, especially among CAPS professionals. Although the representative index of denials, it is believed that the study has not lost the ability to generalize the findings. The municipality of Pelotas has eight CAPS and they all struck up a portion of respondents. Once Pelotas has a greater number of professionals in CAPS than most municipalities, we consider the generalizability of data for similar populations in other regions. It is noteworthy that the lack of studies in the area did not allow comparisons with the greatest results.

\section{Conclusions}

In this study, it can be observed that the CAPS professionals are more adapted to the issues of work, perceive with minor injury to health arising from work and also had a lower prevalence of mental disorders compared to CHA.

New ways of doing the work should always be assessed, and effectiveness of the work we must look in on the point of view of the worker and the feeling or suffering that can come to work or generate is generating. These findings highlight the importance of the mental health of health workers. Often the trivialization of mental suffering as if it were of little importance, and often mental health problems go unnoticed or are not highly valued by workers in the health field. Thus, new ways of doing work in health should always be well analyzed to not compromise worker health and maintain a good service to users of the health system. 


\section{Collaborations}

BS Knuth have made substantial contributions to conception and design, and analysis and interpretation of data; have been involved in drafting the manuscript; and have given final approval of the version to be published. RA Silva and JP Oses have made substantial contributions to conception and design; revising it critically for important intellectual content; and have given final approval of the version to be published. VA Radtke and RA Cocco have made substantial contributions to acquisition of data; have been involved in drafting the manuscript; and have given final approval of the version to be published. $\mathrm{K}$ Jansen have made substantial contributions to conception and design, and analysis and interpretation of data; have been involved in drafting the manuscript; and have given final approval of the version to be published.

\section{Acknowledgments}

The authors express sincere appreciation to the community health workers and Psychosocial Care Centers workers, linked to the Municipal Health Secretariat of Pelotas, RS, Brazil. 


\section{Referências}

1. Azambuja EP, Kerber NPC, Kirchhof AL. A saúde do trabalhador na concepção de acadêmicos de enfermagem. Rev Esc Enferm USP 2007; 41(3):355-362.

2. Trindade LL, Lautert L. Síndrome de Burnout entre os trabalhadores da Estratégia de Saúde da Família. Rev Esc Enferm 2010; 44(2):274-279.

3. World Health Organization (WHO), International Consortium in Psychiatric Epidemiology. Cross-national comparisons of the prevalences and correlates of mental disorders. Bull World Health Organ 2000; 78(4):413-425.

4. Bhugra D. Unemployment, poverty and homelessness. In: Bhugra D, Leff J, editors. Principles of social psychiatry. Oxford: Blackwell Scientific Publications; 1993. p. 355-382.

5. Nussbaumer L, Dapper V, Kalil F. Agravos relacionados ao trabalho notificados no Sistema de Informações em Saúde do Trabalhador no Rio Grande do Sul, 2009. Boletim Epidemiologico 2010; 12(1):5-8.

6. Pitta A. Hospital: dor e morte como ofício. São Paulo: Hucitec; 1994.

7. Finlay-Jones RA, Burvill PW. The prevalence of minor psychiatric morbidity in the community. Psychol Med 1977; 7(3):475-489.

8. Silveira AM. Saúde do trabalhador. Belo Horizonte: Nescon/UFMG, Coopmed; 2009.

9. Mendes EV. A evolução histórica da atenção primária à saúde no Brasil. In: Mendes EV. A atenção primária à saúde no SUS. Fortaleza: Escola de Saúde Pública do Ceará; 2002.

10. Chiesa AM, Fracolli LA. O trabalho dos agentes comunitários de saúde nas grandes cidades: análise do seu potencial na perspectiva da promoção da saúde. Rev Bras Saúde Família 2004; 7:42-49.

11. Onocko-Campos RT, Furtado JP. Entre a saúde coletiva e a saúde mental: um instrumental metodológico para avaliação da rede de Centros de Atenção Psicossocial (CAPS) do Sistema Único de Saúde. Cad Saude Publica 2006; 22(5):1053-1062.

12. Associação Brasileira de Empresas de Pesquisa (ABEP). 2012. [Dados com base no Levantamento Sócio Econômico 2010 - IBOPE]. [acessado 2014 jan 20]. Disponível em: http://www.abep.org

13. Gomes-Oliveira MH, Gorenstein C, Lotufo Neto F, Andrade LH, Wang YP. Validation of the Brazilian Portuguese version of the Beck Depression Inventory-II in a community sample. Rev Bras Psiquiatr 2012; 34(4):389-394.

14. Mari JJ, Williams P. A validity study of a psychiatric screening questionnaire (SRQ-20) in primary care in the city of São Paulo. Br J Psychiatry 1986; 148:23-26.

15. Gonçalves DM, Stein AT, Kapczinski F. Performance evaluation of the Self-Reporting Questionnaire as a psychiatric screening tool: a comparative study with the Structured Clinical Interview for DSM-IV-TR. Cad Saude Publica 2008; 24(2):380-390.
16. Organização Mundial de Saúde (OMS). Relatório sobre a saúde no mundo 2001: Saúde mental: nova concepção, nova esperança. Genebra: OMS; 2001.

17. Dilélio AS, Facchini LA, Tomasi E, Silva SM, Thumé E, Piccini RX, Silveira DS, Maia MFS, Osório A, Siqueira FV, Jardim VMR, Lemões MAM, Borges CLS. Prevalência de transtornos psiquiátricos menores em trabalhadores da atenção primária à saúde das regiões Sul e Nordeste do Brasil. Cad Saude Publica 2012; 28(3):503514.

18. Ludermira AB, Melo Filho DA. Living conditions and occupational structure associated with common mental disorders. Public Health Rev 2002; 36(2):213-221.

19. Bertoletti J, Cabral PMF. Saúde mental do cuidador na instituição hospitalar. Psicologia: Teoria e Pesquisa 2007; 23(1):103-110.

20. Onocko-Campos RT, Furtado JP. Entre a saúde coletiva e a saúde mental: um instrumental metodológico para avaliação da rede de Centros de Atenção Psicossocial (CAPS) do Sistema Único de Saúde. Cad Saude Publica 2006; 22(5):1053-1062.

21. Mielke FB, Kantorski LP, Jardim VMR, Olschowsky A, Machado MS. Mental care delivered in psychosocial care centers (CAPS) from the viewpoint of the professionals. Cien Saude Colet 2009; 14(1):159-164.

22. Silva ATC, Menezes PR. Esgotamento profissional e Transtornos Mentais Comuns em agentes comunitários. Rev Saude Publica 2008; 42(5):921-929.

23. Braga LC, Carvalho LR, Binder MCP, Working conditions and common mental disorder among primary health care workers from Botucatu, São Paulo State. Cien Saude Colet 2010; 15(Supl. 1):1585-1596.

24. Rodrigues EP, Rodrigues US, Oliveira LMM, Laudano RCS, Sobrinho CLN. Prevalence of common mental disorders in nursing workers at a hospital of Bahia. Rev Bras Enferm 2014; 67(2):296-301.

25. Resende MC, Azevedo EGS, Lourenço LR, Faria LS, Alves NF, Farina NP, Silva NC, Oliveira SL. Saúde mental e ansiedade em agentes comunitários que atuam em saúde da família em Uberlândia. Cien Saude Colet 2011; 16(4):2115-2122.

26. Menegolla VL, Polleto DS, Krahl M. O agente comunitário de saúde no desenvolvimento de seu trabalho. Boletim da Saúde 2003; 17(2):81-93.

Artigo apresentado em 24/09/2014

Aprovado em 13/11/2014

Versão final apresentada em 15/11/2014 